\title{
An improved micropropagation via nodal segments of Zingiber officinale
}

 \\ ${ }^{1}$ School of Life Science and Engineering, Southwest University of Science and Technology, Mianyang, Sichuan, \\ People's Republic of China \\ ${ }^{2}$ School of Civil Engineering and Architecture, Southwest University of Science and Technology, Mianyang, Sichuan, \\ People's Republic of China
}

\section{Summary}

An improved micropropagation via nodal segments of Zingiber officinale was described in the present study. Nodal segments containing 1-3 nodes were obtained from 5-weeks old stock shoots and cultured on Murashige and Skoog medium (MS) (Murashige and Skoog, 1962) supplemented with $1 \mathrm{mg} \mathrm{L}^{-1}$ thidiazuron (TDZ) and $0.5 \mathrm{mg} \mathrm{L}^{-1}$ naphthaleneacetic acid (NAA), to promote shoot elongation from axillary buds. With this protocol, more than $90 \%$ of nodal segments containing one and two nodes formed axillary shoots, with 2.2-2.3 shoots per explant produced after 2 weeks of culture. When the shoots were proliferated on MS supplemented with $3 \mathrm{mg} \mathrm{L}^{-1}$ 6-benzylaminopurine (BAP) and $0.2 \mathrm{mg} \mathrm{L}^{-1} \mathrm{NAA}, 6.3$ shoots per explant with well-developed roots, each shoot being $6.2 \mathrm{~cm}$ in length, were obtained after 5 weeks of proliferation. The plants were established in soil following acclimatization. Analysis of inter simple sequence repeat (ISSR) and random amplified polymorphic DNA (RAPD) did not detect any polymorphic bands in micropropagated plants. To the best of our knowledge, this is the first report on micropropagation using nodal segments of ginger native to China. Results reported here provide a technical support for micropropagation of Zingiber spp.

Keywords

ginger, nodal segments, axillary shoot formation, genetic stability

\section{Introduction}

Ginger (Zingiber officinale), a perennial herbaceous plant, is mainly grown in Asia, including India, China, Thailand, Nepal, Japan, Indonesia, and Sri Lanka (Seran, 2013; Wilson et al., 2013). Currently, India and China are the major ginger producing countries of the world. Ginger is widely used as a spice in food (Seran, 2013), beverage (Seran, 2013) and a medicine for anti-inflammatory, cancer prevention, post-operative anti-emetic, and mental disorders (Grzanna et al., 2005; Chaiyakunapruk et al., 2006; Shukla and Singh, 2007; Yi et al., 2009; Seran, 2013; Wilson et al., 2013; Prasad and Tyagi, 2015; Ali et al., 2018).

Ginger is vegetatively propagated and the conventional propagation of ginger by matured rhizomes division resulted in low multiplication rates (Seran, 2013; Abbas et al., 2018), and virus accumulation in the progenies (Wang and Valkonen,

\section{Significance of this study}

What is already known on this subject?

- Most of the previous studies of ginger

micropropagation focused on indirect shoot regeneration, while only a few described direct shoot regeneration. Nodal segments with one node were frequently used as explants.

What are the new findings?

- An improved micropropagation via nodal segments was described for Zingiber officinale native to China. Genetic stability was assessed in micropropagated plants using ISSR and RAPD.

What is the expected impact on horticulture?

- Results reported here provide a technical support for micropropagation of Zingiber spp.

2009; Legg et al., 2015). In vitro culture technique provides an alternative method for efficient shoot regeneration and rapid micropropagation of virus-free plants of ginger (Sharma and Singh, 1997; Seran, 2013; Abbas et al., 2018). In vitro cultures can also be used for preserving ginger germplasm (Tyagi et al., 2006; Sundararaj et al., 2010) and production of virus-free ginger plants (Sharma and Singh, 1997; Manisha et al., 2018). In vitro shoot regeneration of ginger has been established using various explants such as shoot tips (Noguchi and Yamakawa, 1988; Malamug et al., 1991; Rout et al., 2001; Rajani and Patil, 2009; Ibrahim et al., 2015; Ali et al., 2018), immature inflorescence (Babu et al., 1992a), aerial stem buds (Sharma and Singh, 1997; Lincy et al., 2009; Rajani and Patil, 2009; Lincy and Sasikumar, 2010; Manisha et al., 2018), leaf segments (Babu et al., 1992b; Mehaboob et al., 2019), stem segments (Noguchi and Yamakawa, 1988), rhizome buds (Balachandran et al., 1990; Kambaska and Santilata, 2009; Abbas et al., 2011; Mohanty et al., 2011), and thin cell sections of microrhizomes (Thingbaijam and Huidrom, 2014).

Further improvements of in vitro shoot regeneration would facilitate wider applications of biotechnology in ginger. It is well-known that genotype-specific is very common in vitro shoot regeneration and a regeneration system suitable for some genotypes may not be suitable for other genotypes in a given species (George et al., 2008). Studies on in vitro shoot regeneration of ginger native to China were quite limited. Therefore, developments of in vitro shoot regeneration protocols of China's ginger genotypes are of significance.

Genetic stability is a major concern in in vitro regener- 
ants, and was investigated in a number of plants including perennial species like apple (Li et al., 2014) and grapevine (Bi et al., 2018), and annual ones like lily (Yin et al., 2013) and potato (Wang et al., 2014). However, such studies have been quite limited in Zingiber (Mohanty et al., 2011).

The objective of the present study was, therefore, to develop an efficient micropropagation using nodal segments of Z. officinale native to China. Genetic stability was assessed in the regenerants using inter-simple sequence repeat markers (ISSR) and random amplified polymorphic DNA (RAPD).

\section{Materials and methods}

\section{Plant materials, culture media and conditions}

Z. officinale 'Qianwei', a cultivar widely grown in southwest China (Zhang et al., 2012), was used in the present study. Matured rhizomes collected in 2018 from commercial ginger field in Leshan City, China, were surface-disinfected with $0.1 \%$ mercuric chloride $\left(\mathrm{HgCl}_{2}\right)$ for $20 \mathrm{~min}$, followed by rinsing three times with sterile distilled water. Buds were isolated from the surface-disinfected rhizomes and cultured on a basic medium (BM) composed of Murashige and Skoog's (MS) medium (Murashige and Skoog, 1962) supplemented with $30 \mathrm{~g} \mathrm{~L}^{-1}$ sucrose and $7 \mathrm{~g} \mathrm{~L}^{-1}$ agar (Sigma Chemical Co., St. Louis, MO, USA). The $\mathrm{pH}$ of the medium was adjusted to 5.8 with $1 \mathrm{M} \mathrm{NaOH}$, prior to autoclaving at $121^{\circ} \mathrm{C}$ for $20 \mathrm{~min}$. The cultures were grown at $25 \pm 2^{\circ} \mathrm{C}$ under a 16 -h photoperiod of $45 \mu \mathrm{mol} \mathrm{m}{ }^{-2} \mathrm{~s}^{-1}$ provided by cool-white fluorescent tubes. After 7 days of culture, the cultures were transferred on a shoot maintenance medium (SMM) and cultured in the same conditions for production of in vitro stock shoots. SMM was composed of BM supplemented with $1 \mathrm{mg} \mathrm{L}^{-1} \alpha$-naphthaleneacetic acid (NAA). In vitro stock shoots were subcultured every 5 weeks.

Five-week-old stock shoots (Figure 1a) were used for obtaining nodal segments. After removal of leaves from basal parts of the stock shoots (Figure 1b), nodal segments containing one node (2-3 mm in length, Figure 1c), two nodes
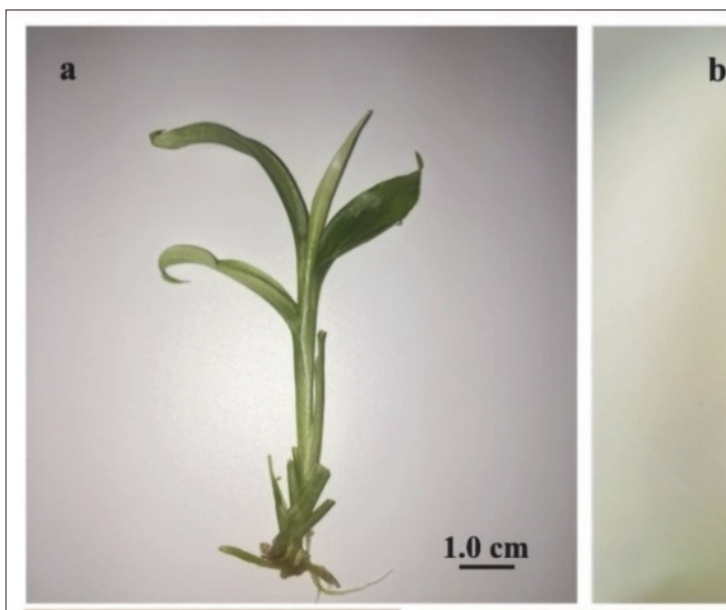

b

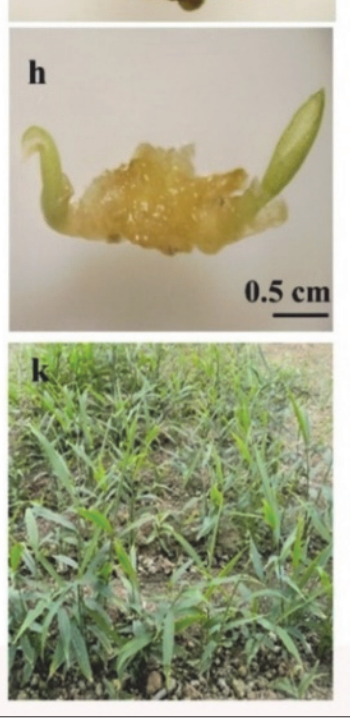

FigURE 1. Preparation of nodal segments, shoot formation and proliferation, and re-establishment of micropropagated plants in soil of Zingiber officinale 'Qianwei'. a. An in vitro stock shoot used for excision of nodal segments for shoot formation; b. Preparation of a nodal segment, as indicated by a red rectangle; Segments with one node (2-3 mm in length, c); two nodes (5-6 mm in length, d); three nodes (8-10 $\mathrm{mm}$ in length, e); f. An axillary bud on a node, as indicated by a white arrow; g. A small shoot elongating from an axillary bud on the surface of a nodal segment at day 3 of culture, as indicated by a red circle; h. Shoots $(0.5-1.0 \mathrm{~cm}$ in length) formed in a nodal segment at day 12 of culture; i. A shoot with 3 fully-opened leaves after 2 weeks of culture on SFM5; j. Proliferating shoots with well-developed roots on SPM8 after 5 weeks of proliferation; k. Micropropagated plants re-established in soil in open field for three months. 
TABLE 1. Effect of size of nodal segments and combination of TDZ and NAA on shoot formation of Zingiber officinale 'Qianwei'.

\begin{tabular}{|c|c|c|c|c|c|}
\hline \multirow{2}{*}{$\begin{array}{l}\text { Nodal segments } \\
\text { containing }\end{array}$} & \multirow{2}{*}{$\begin{array}{l}\text { Code of shoot formation } \\
\text { medium (SFM) }\end{array}$} & \multicolumn{2}{|c|}{ Plant growth regulators } & \multirow[b]{2}{*}{$\begin{array}{l}\text { Shoot formation } \\
(\%)\end{array}$} & \multirow{2}{*}{$\begin{array}{c}\text { Number of shoots } \\
\text { nodal segment }\end{array}$} \\
\hline & & $\begin{array}{c}\text { TDZ } \\
\left(\mathrm{mg} \mathrm{L}^{-1}\right)\end{array}$ & $\begin{array}{c}\text { NAA } \\
\left(\mathrm{mg} \mathrm{L}^{-1}\right)\end{array}$ & & \\
\hline \multirow[t]{6}{*}{ One node } & SFM 1 & 0.5 & 0 & $86.7 \pm 6.7 a b$ & $1.7 \pm 0.1 v$ \\
\hline & SFM 2 & 0.5 & 0.5 & $76.7 \pm 3.3 a b c$ & $1.3 \pm 0.1 y$ \\
\hline & SFM 3 & 0.5 & 1.0 & $76.7 \pm 3.3 \mathrm{abc}$ & $1.7 \pm 0.2 \mathrm{v}$ \\
\hline & SFM 4 & 1.0 & 0 & $83.3 \pm 3.3 a b$ & $1.5 \pm 0.2 v w x$ \\
\hline & SFM 5 & 1.0 & 0.5 & $90.0 \pm 5.8 a$ & $2.3 \pm 0.1 \mathrm{tu}$ \\
\hline & SFM 6 & 1.0 & 1.0 & $86.7 \pm 3.3 a b$ & $1.7 \pm 0.1 \mathrm{v}$ \\
\hline Average & & & & 83.4 & 1.7 \\
\hline \multirow[t]{6}{*}{ Two nodes } & SFM 1 & 0.5 & 0 & $76.7 \pm 5.8 \mathrm{abc}$ & $1.5 \pm 0.1$ vwxy \\
\hline & SFM 2 & 0.5 & 0.5 & $63.3 \pm 3.3 \mathrm{cde}$ & $1.4 \pm 0.1 w x y$ \\
\hline & SFM 3 & 0.5 & 1.0 & $80.0 \pm 5.8 \mathrm{abc}$ & $1.7 \pm 0.1 v$ \\
\hline & SFM 4 & 1.0 & 0 & $70.0 \pm 3.3 \mathrm{bcd}$ & $1.5 \pm 0.1 \mathrm{vwxy}$ \\
\hline & SFM 5 & 1.0 & 0.5 & $93.3 \pm 3.3 \mathrm{a}$ & $2.2 \pm 0.1 u$ \\
\hline & SFM 6 & 1.0 & 1.0 & $76.7 \pm 3.3 a b c$ & $1.6 \pm 0.1 v w$ \\
\hline Average & & & & 76.7 & 1.7 \\
\hline \multirow[t]{6}{*}{ Three nodes } & SFM 1 & 0.5 & 0 & $46.7 \pm 3.3 \mathrm{ef}$ & $1.6 \pm 0.1 \mathrm{vw}$ \\
\hline & SFM 2 & 0.5 & 0.5 & $53.3 \pm 3.3 \mathrm{def}$ & $1.3 \pm 0.2 x y$ \\
\hline & SFM 3 & 0.5 & 1.0 & $36.7 \pm 3.3 f$ & $1.5 \pm 0.1 v w x y$ \\
\hline & SFM 4 & 1.0 & 0 & $53.3 \pm 3.3 \mathrm{def}$ & $1.1 \pm 0.1 z$ \\
\hline & SFM 5 & 1.0 & 0.5 & $53.3 \pm 3.3$ def & $2.4 \pm 0.1 \mathrm{t}$ \\
\hline & SFM 6 & 1.0 & 1.0 & $36.7 \pm 6.7 f$ & $1.6 \pm 0.1 \mathrm{vw}$ \\
\hline Average & & & & 46.7 & 1.6 \\
\hline
\end{tabular}

One node (2-3 mm in length), two nodes (5-6 mm in length) and three nodes (8-10 $\mathrm{mm}$ in length) were cultured on SFM for shoot formation. Results are presented as means $\pm \mathrm{SE}$, and with different letters in the same column indicate significant differences at $P<0.05$ analyzed by Duncan's multiple range test.

TABLE 2. Effects of combinations of BAP and NAA in shoot proliferation medium on shoot proliferation of Zingiber officinale 'Qianwei'.

\begin{tabular}{|c|c|c|c|c|}
\hline \multirow[b]{2}{*}{$\begin{array}{l}\text { Code of shoot proliferation } \\
\text { medium }\end{array}$} & \multicolumn{2}{|c|}{ Plant growth regulators } & \multirow{2}{*}{$\begin{array}{c}\text { Number of } \\
\text { proliferating } \\
\text { shoots/explant }\end{array}$} & \multirow{2}{*}{$\begin{array}{l}\text { Shoot length } \\
\quad(\mathrm{cm})\end{array}$} \\
\hline & $\begin{array}{c}\text { BAP } \\
\left(\mathrm{mg} \mathrm{L}^{-1}\right)\end{array}$ & $\begin{array}{c}\text { NAA } \\
\left(\mathrm{mg} \mathrm{L}^{-1}\right)\end{array}$ & & \\
\hline SPM 1 & 1.0 & 0.1 & $3.2 \pm 0.1 \mathrm{e}$ & $3.7 \pm 0.2 y z$ \\
\hline SPM 2 & 1.0 & 0.2 & $2.6 \pm 0.1 \mathrm{~g}$ & $3.0 \pm 0.3 z$ \\
\hline SPM 3 & 1.0 & 0.5 & $4.2 \pm 0.1 d$ & $4.5 \pm 0.3 w x y$ \\
\hline SPM 4 & 2.0 & 0.1 & $3.1 \pm 0.1 \mathrm{ef}$ & $4.4 \pm 0.2 x y$ \\
\hline SPM 5 & 2.0 & 0.2 & $4.7 \pm 0.2 \mathrm{c}$ & $5.1 \pm 0.4 \mathrm{vwx}$ \\
\hline SPM 6 & 2.0 & 0.5 & $2.7 \pm 0.1 \mathrm{fg}$ & $4.7 \pm 0.3 v w x$ \\
\hline SPM 7 & 3.0 & 0.1 & $5.3 \pm 0.2 b$ & $5.6 \pm 0.3 u v$ \\
\hline SPM 8 & 3.0 & 0.2 & $6.3 \pm 0.1 \mathrm{a}$ & $6.2 \pm 0.2 u$ \\
\hline SPM 9 & 3.0 & 0.5 & $5.5 \pm 0.2 b$ & $5.4 \pm 0.1 \mathrm{uvw}$ \\
\hline
\end{tabular}

Shoots were cultured on 9 SPM for shoot proliferation. SPM was composed of BM supplemented with different combination of BAP and NAA. Data were presented as means \pm SE, and with different letters in the same column indicate significant differences at $P<0.05$ analyzed by Duncan's multiple range test.

(5-6 $\mathrm{mm}$ in length, Figure $1 \mathrm{~d})$ or three nodes $(8-10 \mathrm{~mm}$ in length, Figure 1e) were obtained. The nodal segments were cultured on six shoot elongation media (SEM) (Table 1), to promote shoot elongation from axillary buds. The culture condition was the same as used for production of in vitro stock shoots. Shoot formation percentages and number of shoots per nodal segment were recorded after 14 days of culture.

\section{Shoot proliferation}

Shoots ( $>2.0 \mathrm{~cm}$ in length) were excised from the nodal segments after 4 weeks of culture and transferred on 9 different shoot proliferation media (SPM), to select an optimal SPM for shoot multiplication (Table 2). The culture condition was the same as used for production of in vitro stock shoots. Number of proliferating shoots per shoot and shoot length were recorded after five weeks of culture. 
TABLE 3. ISSR primer names, sequences, and number of amplified bands in micropropagated plants of Zingiber officinale 'Qianwei'.

\begin{tabular}{|c|c|c|c|c|c|}
\hline Number & Primers & Sequence & Reference & $\begin{array}{c}\text { Number of } \\
\text { amplified bands }\end{array}$ & $\begin{array}{c}\text { Number of } \\
\text { polymorphic bands }\end{array}$ \\
\hline 1 & SPS03 & $(\mathrm{GACA})_{4}$ & \multirow[t]{3}{*}{ Mohanty et al., 2011} & 4 & 0 \\
\hline 2 & SPS05 & $(\mathrm{GA})_{9} \mathrm{~T}$ & & 5 & 0 \\
\hline 3 & SPS06 & $\mathrm{T}(\mathrm{GA})_{9} \mathrm{~T}$ & & 3 & 0 \\
\hline 4 & IS1 & $(\mathrm{CT})_{7} \mathrm{TG}$ & Yamuna et al., 2007 & 5 & 0 \\
\hline 5 & ISSR02 & $(\mathrm{AGTG})_{3}$ & \multirow{9}{*}{$\begin{array}{l}\text { Kizhakkayil and } \\
\text { Sasikumar, } 2010\end{array}$} & 4 & 0 \\
\hline 6 & ISSR05 & $(\mathrm{CT})_{7} \mathrm{TG}$ & & 6 & 0 \\
\hline 7 & ISSR06 & $(\mathrm{GA})_{8} \mathrm{C}$ & & 7 & 0 \\
\hline 8 & ISSR07 & $(G A)_{8} G$ & & 5 & 0 \\
\hline 9 & ISSR08 & $(\mathrm{GA})_{8} \mathrm{~T}$ & & 5 & 0 \\
\hline 10 & ISSR09 & $(\mathrm{CT})_{8} \mathrm{G}$ & & 3 & 0 \\
\hline 11 & ISSR12 & $(\mathrm{CAC})_{3} \mathrm{GC}$ & & 7 & 0 \\
\hline 12 & ISSR14 & $(A G C)_{4} G T$ & & 6 & 0 \\
\hline \multirow[t]{2}{*}{13} & ISSR16 & $(\text { GAGAGA })_{2}$ GAGAT & & 5 & 0 \\
\hline & Total & & & 65 & 0 \\
\hline
\end{tabular}

\section{Establishment of plants in soil}

Proliferated shoots (5-6 cm in length) with 3-4 fully opened leaves and well-developed roots were transferred into plastic pots (12 $\mathrm{cm}$ in diameter) containing a mixture of sterile soil: sand: coir dust: cow dung (3:1:1:1) and grown in greenhouse conditions. The pots were covered with plastic bags to maintain high humidity and gradually opened to reduce the humidity in a week. After two weeks of growth in greenhouse, the plants were re-established in soil in field conditions.

\section{Assessment of genetic stability}

Genetic stability was assessed in micropropagated plants after three months of growth in soil in the open filed, using inter simple sequence repeat (ISSR) and random amplified polymorphic DNA (RAPD).

\section{DNA extraction}

Genomic DNA was isolated from $0.5 \mathrm{~g}$ fresh leaf tissue of the samples, according to Doyle and Doyle (1990). Purified total DNA was quantified and its quality verified by ultraviolet spectrophotometry. Each sample was diluted to $50 \mathrm{ng} \mu \mathrm{L}^{-1}$ in Tris-EDTA buffer and stored at $-20^{\circ} \mathrm{C}$ until use.

\section{ISSR}

Twenty-two primer pairs were screened to select suitable primers for amplifying PCR products, according to Mohanty et al. (2011), Yamuna et al. (2007), and Kizhakkayil and Sasikumar (2010) (Table 3). Procedures of PCR were conducted according to Yamuna et al. (2007). After amplification, the PCR products were separated by electrophoresis and revealed by silver staining according to the method of Bassam et al. (1991).

\section{RAPD}

Fifteen RAPD primer pairs were screened to select suitable primers for amplifying PCR products, according to Mohanty et al. (2011) (Table 4). Procedures of PCR were conducted according to Yamuna et al. (2007) and polyacrylamide gel electrophoresis of PCR products performed, as described by Bassam et al. (1991).

\section{Experimental design and statistical analysis of data}

In experiments of shoot formation and proliferation, 10 explants were included in each of three replicates. The whole experiment was performed twice. Results are presented as means \pm SE. Data were analyzed using one-way ANOVA and significant differences were calculated at $P<0.05$ by Duncan's

TABLE 4. RAPD primer names, sequences, and number of amplified bands in micropropagated plants of Zingiber officinale 'Qianwei'.

\begin{tabular}{|c|c|c|c|c|c|}
\hline Number & Primers & Sequence & Reference & Number of amplified bands & $\begin{array}{c}\text { Number of } \\
\text { polymorphic bands }\end{array}$ \\
\hline 1 & OPA07 & GAAACGGGTG & \multirow{8}{*}{$\begin{array}{l}\text { Mohanty et al., } \\
2011\end{array}$} & 9 & 0 \\
\hline 2 & OPA09 & GGGTAACGCC & & 5 & 0 \\
\hline 3 & OPC02 & GTGAGGCGTC & & 6 & 0 \\
\hline 4 & OPC05 & GATGACCGCC & & 3 & 0 \\
\hline 5 & OPD03 & GTCGCCGTCA & & 3 & 0 \\
\hline 6 & OPD07 & TTGGCACGGG & & 4 & 0 \\
\hline 7 & OPD20 & ACCCGGTCAC & & 5 & 0 \\
\hline \multirow[t]{2}{*}{8} & OPN04 & GACCGACCCA & & 2 & 0 \\
\hline & Total & & & 37 & 0 \\
\hline
\end{tabular}


multiple range test. Thirty samples were randomly selected from each of micropropagated plants and in vitro stock shoots (control) and used for assessment of genetic stability. Bands were scored as present (1) or absent (0). Bands of equal molecular weight and mobility generated by the same primer were considered to represent the same locus. Both distinct monomorphic bands and polymorphic bands were scored. The experiments were repeated twice to confirm their repeatability, and only reliable and repeatable bands were included in the data analysis.

\section{Results}

\section{Overall process of shoot formation, proliferation and} plant establishment in soil

Axillary buds were observed in nodes of the stem under a microscope (Figure 1f). Axillary buds started to elongate, with visible shoots $(0.5-1.0 \mathrm{~mm})$ formed on surface of nodal segments at day 3 of culture (Figure $1 \mathrm{~g}$ ). These small shoots continued to grow and formed shoots $(0.5-1.0 \mathrm{~cm})$ in nodal segments containing one node or two nodes at day 12 of culture (Figure $1 \mathrm{~h}$ ). Shoots ( $\geq 2.0 \mathrm{~cm}$ in length) with $3-4$ open leaves developed after 4 weeks of culture on SFM (Figure 1i). Proliferating shoots with well-developed roots (Figure $1 \mathrm{j}$ ) were produced after five weeks of culture on SPM. Micropropagated plants were successfully re-established and grew normally in soil in the open field (Figure $1 \mathrm{k}$ ).
Effects of the size of nodal segments and combination of TDZ and NAA on shoot formation

Although three sizes of nodal segments formed shoots when cultured on SFM containing different combinations of TDZ and NAA concentrations, size of nodal segments and combination of TDZ and NAA concentration in SFM significantly influenced shoot formation (Table 1). Nodal segments containing one, two and three nodes produced average shoot formation of $83.4 \%, 76.7 \%$ and $46.7 \%$, respectively, regardless of the combinations of TDZ and NAA concentrations (Table 1). When cultured on SFM5, nodal segments containing one and two nodes produced $90.0 \%$ and $93.3 \%$ shoot formation, and 2.3 and 2.2 shoots per nodal segment (Table 1). These were the optimal results of shoot formation obtained among the 18 media tested in the present study. Therefore, SFM5 containing $1.0 \mathrm{mg} \mathrm{L}^{-1} \mathrm{TDZ}$ and $0.5 \mathrm{mg} \mathrm{L}^{-1} \mathrm{NAA}$ was consistently used for shoot formation in nodal segments in the present study.

\section{Effect of combination of BAP and NAA on shoot proliferation}

Although shoots could be proliferated on the nine SPM tested, combination of BAP (1.0-3.0 $\left.\mathrm{mg} \mathrm{L}^{-1}\right)$ and NAA (0.1-0.5 $\mathrm{mg} \mathrm{L}^{-1}$ ) considerably affected shoot proliferation (Table 2). SPM8 containing $3.0 \mathrm{mg} \mathrm{L}^{-1} \mathrm{BAP}$ and $0.2 \mathrm{mg} \mathrm{L}^{-1} \mathrm{NAA}$ produced the best shoot proliferation (Figure 1j; Table 2): 6.3 shoots per explant and $6.2 \mathrm{~cm}$ shoot length. Therefore, SPM8 was consistently used for shoot proliferation in the present study.

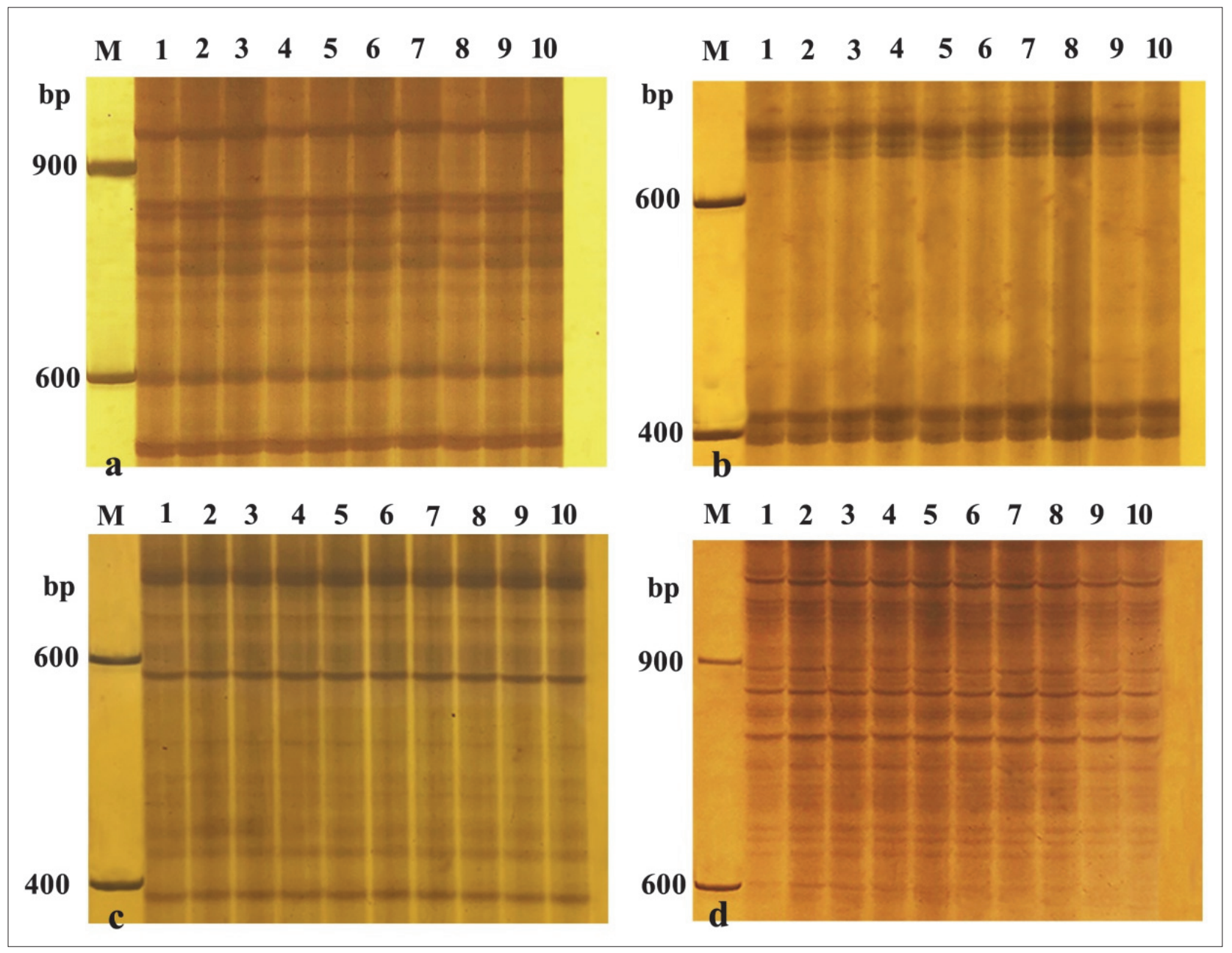

FIGURE 2. ISSR (a, primer ISSR06 and b, primer ISSR16) and RAPD (c, primer OPD 03 and d, OPD 07) banding patterns in micropropagated plants of Zingiber officinale 'Qianwei' after 3 months of re-establishment in soil. M marker=DL2000, lanes $1-2=$ in vitro stock shoots, lanes $3-10=$ micropropagated plants. 


\section{Assessment of genetic stability}

1. ISSR. Thirteen primers selected from 22 primers produced clear and reproducible bands and yielded 65 scored bands in each samples (Table 3; Figures 2a, b), with total 1,950 bands produced across the 30 samples analyzed. The number of bands for each primer varied from 3 to 7 (Table 3), with an average of 5 bands per primer. No polymorphic bands were detected in the micropropagated plants tested (Table 3; Figures 2a, b).

2. RAPD. Eight primers selected from 15 primers produced clear and reproducible bands and yielded 37 scored bands in each sample (Table 4; Figures 2c, d), with a total of 1,110 bands produced across the 30 samples analyzed. The number of bands for each primer varied from 2 to 9 (Table 4), with an average of 4.6 bands per primer. No polymorphic bands were tested in the micropropagated plants (Table 4; Figures 2c, d).

\section{Discussion}

Compared with the previous reports of shoot regeneration using nodal segments (Noguchi and Yumakawa, 1988) and aerial stem segments of ginger (Lincy and Sasikumar, 2010), two significant improvements were made in the present study. First, nodal segments with one node (Noguchi and Yumakawa, 1988) and aerial stem segments $(1.0-1.5 \mathrm{~cm})$ (Lincy and Sasikumar, 2010) were used as initial explants. In the present study, nodal segments with 1-3 nodes were compared for shoot formation, and identified the size of the nodal segments exerted significant effects of shoot formation in ginger. Second, more than 3 months and 140-148 days were required to complete the micropropagation cycle using stem segments (Noguchi and Yumakawa, 1988) and aerial stem segment (Lincy and Sasikumar, 2010) as initial explants. In the present study, about 9 weeks were required to complete the micropropagation cycle and 28-58 plantlets/ initial explant can be produced using nodal segments as the initial explants. These two improvements largely simplified the procedure and shortened the time required in micropropagation of ginger. Therefore, the protocol described in the present study can be considered an improved protocol for efficient micropropagation of ginger.

Plant growth regulators (PGRs) play a critical role in shoot regeneration and proliferation of ginger (Seran, 2013). TDZ and BAP alone or in combination with auxin was frequently used to induce adventitious shoot formation (Seran, 2013). Working on Z. officinale 'Kintoki', Noguchi and Yamakawa (1988) reported that $1.0 \mathrm{mg} \mathrm{L}^{-1} \mathrm{BAP}$ produced the highest number (6.3) of shoots from shoot tips, while a combination of $3.0 \mathrm{mg} \mathrm{L}^{-1} \mathrm{BAP}$ and $5.0 \mathrm{mg} \mathrm{L}^{-1} \mathrm{NAA}$ was optimal for shoot regeneration from leaf segments. The best results of shoot regeneration were obtained in transverse thin cell layer sections (tTCLSs) of 'Nadia' microrhizome when cultured with a combination of $2.0-6.0 \mathrm{mg} \mathrm{L}^{-1} \mathrm{BAP}$ with $0.2 \mathrm{mg} \mathrm{L}^{-1}$ 2,4-D (Thingbaijam and Huidrom, 2014). Among the different combination of PGRs tested, a combination of $1.0 \mathrm{mg} \mathrm{L}^{-1}$ TDZ with $1.0 \mathrm{mg} \mathrm{L}^{-1}$ IBA produced maximum shoot regeneration in stem segments of 'Jamaica' and 'Varada' (Lincy and Sasikumar, 2010). The present study found a combination of $1.0 \mathrm{mg} \mathrm{L}^{-1} \mathrm{TDZ}$ with $0.5 \mathrm{mg} \mathrm{L}^{-1} \mathrm{NAA}$ producing the best results of shoot formation from nodal segments of ginger 'Qianwei'.

There have been a number of studies on shoot proliferation in ginger. Although Mehaboob et al. (2019) reported the highest number of proliferating shoots was obtained on shoot proliferation medium containing $0.5 \mathrm{mg} \mathrm{L}^{-1} \mathrm{BAP}$ alone, most of the studies used a combination of BAP with IBA or
NAA for shoot proliferation. Kambaska and Santilata (2009) reported that $2.0 \mathrm{mg} \mathrm{L}^{-1} \mathrm{BAP}$ and $0.5 \mathrm{mg} \mathrm{L}^{-1} \mathrm{NAA}$ gave an average of 7.5 shoots in ginger 'Suprava' and 'Suruchi', and a higher concentration of BAP (2.5-3.0 mg L' $\mathrm{m}^{-1}$ ) induced callus formation and produced fewer number of shoots. Zuraida et al. (2016) reported that the highest number of proliferating shoots of 'Rubrum' were obtained when cultured in the medium containing $3.0 \mathrm{mg} \mathrm{L}^{-1} \mathrm{BAP}$ and $0.5 \mathrm{mg} \mathrm{L}^{-1} \mathrm{NAA}$. The present study found that shoot proliferation medium containing $3.0 \mathrm{mg} \mathrm{L}^{-1} \mathrm{BAP}$ and $0.2 \mathrm{mg} \mathrm{L}^{-1} \mathrm{NAA}$ was optimal for shoot proliferation of ginger 'Qianwei'. The differences in combinations of PGRs for shoot proliferation are most likely due to types of ginger genotypes.

The genetic stability is a major concern in in vitro-derived plants and therefore, assessment of genetic stability in regenerants is necessary (Yin et al., 2013). Molecular markers such as ISSR and RAPD were among the most widely used techniques for this purpose. Use of more than one marker system would produce more reliable results of genetic integrity analyses (Wang et al., 2014; Anandan et al., 2018). Information on assessment of genetic stability in the regenerants is lacking in Z. officinale. Mohanty et al. (2011) applied RAPD and ISSR to assess the genetic stability in the regenerants through the rhizome buds of $Z$. rubens and did not detect any polymorphic bands. The results of the present study are in line with those of Mohanty et al. (2011), indicating that the regenerants are genetically stable.

\section{Conclusions}

An improved micropropagation via nodal segments as initial explants was described for Z. officinale. To the best of our knowledge, this is the first report on in vitro micropropagation from nodal segments of ginger native to China. Results reported here provide technical support for in vitro micropropagation of Zingiber spp.

\section{Acknowledgments}

The authors acknowledge financial support from the fund provided by Lefu Biotechnology Co., Ltd. (Leshan City, China, 17zh0279) and College students' innovation project of Sichuan Province (18xcy065).

\section{References}

Abbas, M.S., Taha, H.S., Aly, U., El-Shabrawi, H.M., and Gaber, E.S. (2011). In vitro propagation of ginger (Zingiber officinale Rosc.) J. Genet. Eng. Biotech. 9(2), 165-172. https://doi.org/10.1016/j. jgeb.2011.11.002.

Abbas, M.S., Aly, U., Taha, H., and Gaber, E.S. (2018). In vitro propagation of microrhizomes in ginger (Zingiber officinale Rosc.). J. Microbiol. Biotech. Food Sci. 4(2), 142-148. https://doi. org/10.15414/jmbfs.2014.4.2.142-148.

Ali, A.M.A., El-Nour, M.E.M., and Yagi, S.M. (2018). Total phenolic and flavonoid contents and antioxidant activity of ginger (Zingiber officinale Rosc.) rhizome, callus and callus treated with some elicitors. J. Genet. Eng. Biotech. 16(2), 677-682. https://doi. org/10.1016/j.jgeb.2018.03.003.

Anandan, R., Prakash, M., Deenadhayalan, T., Nievetha, R., and Kumar, N.S. (2018).Efficient in vitro plant regeneration from cotyledon-derived callus culture of sesame (Sesamum indicum L.) and genetic analysis of True-to-Type regenerants using RAPD and SSR markers. S. Afr. J. Bot. 119, 244-251. https://doi.org/10.1016/j.sajb.2018.09.020.

Babu, K.N., Samsudden, K., and Ravindran, P.N. (1992a). Direct regeneration of plantlets from immature inflorescence of ginger (Zingiber officinale Rosc.) by tissue culture. J. Spic. Arom. Crops 1, 43-48. 
Babu, K.N., Samsudeen, K., and Ratnambal, M.J. (1992b). In vitro plant regeneration from leaf-derived callus in ginger (Zingiber officinale Rosc.). Plant Cell Tiss. Org. 29(2), 71-74. https://doi.org/10.1007/ BF00033610.

Balachandran, S.M., Bhat, S.R., and Chandel, K.P.S. (1990). In vitro clonal multiplication of turmeric (Curcuma spp.) and ginger (Zingiber officinale Rosc.). Plant Cell Rep. 8(9), 521-524. https://doi. org/10.1007/BF00820200.

Bassam, B.J., Caetano-Anollés, G., and Gresshoff, P.M. (1991). Fast and sensitive sliver staining of DNA in polyacrylamide gels. Anal. Biochem. 196(1), 80-83. https://doi.org/10.1016/0003-2697(91)90120-I.

Bi, W.L., Hao, X.Y., Cui, Z.H., Volk, G.M., and Wang, Q.C. (2018) Droplet-vitrification cryopreservation of in vitro-grown shoot tips of grapevine (Vitis spp.). In Vitro Cell. Dev.-Plant 54(6), 590-599. https://doi.org/10.1007/s11627-018-9931-0.

Chaiyakunapruk, N., Kitikannakorn, N., Nathisuwan, S., Leeprakobboon, K., and Leelasettagool, C. (2006). The effect of ginger for the prevention of postoperative nausea and vomiting: A meta-analysis. Am. J. Obstet. Gynaecol. 194(1), 95-99. https://doi. org/10.1016/j.ajog.2005.06.046.

Doyle, J.J., and Doyle, J.L. (1990). A rapid DNA isolation procedure for small quantities of fresh leaf tissue. Phytochemistry 19(1), 11-15. https://doi.org/10.2307/2419362.

George, E.F., Hall, M.A., and De Klerk, G.J. (2008). Adventitious regeneration. In Plant Propagation by Tissue Culture, Vol. 1, The Background (Dordrecht, The Netherlands: Springer Science \& Business Media).

Grzanna, R., Lindmark, L., and Frondoza, C. (2005). Ginger - An herbal medicinal product with broad anti-inflammatory actions. J. Med. Food 8(2), 125-132. https://doi.org/10.1089/jmf.2005.8.125.

Ibrahim, D.A., Danial, G.H., Mosa, V.M., and Khalil, B.M. (2015). Plant regeneration from shoot tips-derived callus of ginger (Zingiber officinale Rosc.). Am. J. Exp. Agr. 7(1), 55-61. https://doi. org/10.9734/AJEA/2015/13980.

Kambaska, K.B., and Santilata, S. (2009). Effect of plant growth regulator on micropropagation of ginger (Zingiber officinale Rosc.) cv. Suprava and Suruchi. J. Agric. Technol. 5(5), 271-280.

Kizhakkayil, J., and Sasikumar, B. (2010). Genetic diversity analysis of ginger (Zingiber officinale Rosc.) germplasm based on RAPD and ISSR markers. Sci. Hortic. 125(1), 73-76. https://doi.org/10.1016/j. scienta.2010.02.024.

Legg, J.P., Lava Kumar, P., Makeshkumar, T., Tripathi, L., Ferguson, M., Kanju, E., Ntawuruhunga, P., and Ceullar, W. (2015). Cassava virus diseases: Biology, epidemiology, and management. Adv. Virus Res. 91, 85-142. https://doi.org/10.1016/bs.aivir.2014.10.001.

Li, B.Q., Feng, C.H., Hu, L.Y., Wang, M.R., Chen, L., and Wang, Q.C. (2014). Shoot regeneration and cryopreservation of shoot tips of apple (Malus) by encapsulation-dehydration. In Vitro Cell. Dev. Biol. Plant. 50(3), 357-368. https://doi.org/10.1007/s11627-014-9616-2.

Lincy, A.K., and Sasikumar, B. (2010). Enhanced adventitious shoot regeneration from aerial stem explants of ginger using TDZ and its histological studies. Turk. J. Bot. 34(1), 21-29.

Lincy, A.K., Remashree, A.B., and Sasikumar, B. (2009). Indirect and direct somatic embryogenesis from aerial stem explants of ginger (Zingiber officinale). Acta Bot. Croat. 68(1), 93-103.

Malamug, J.J.F., Inden, H., and Asahira, T. (1991). Plantlet regeneration and propagation from ginger callus. Sci. Hortic. 48(1-2), 89-97. https://doi.org/10.1016/0304-4238(91)90155-R.

Manisha, T., Vishal, S., and Garima, K. (2018). In vitro production of disease free planting material of ginger (Zingiber officinale Rosc.) A single step procedure. Res. J. Biotech. 13(3), 25-29.
Mehaboob, V.M., Faizal, K., Raja, P., Thiagy, G., Aslam, A., and Shajahan, A. (2019). Effect of nitrogen sources and 2,4-D treatment on indirect regeneration of ginger (Zingiber officinale Rosc.) using leaf base explants. J. Plant Biotechnol. 46, 17-21. https://doi.org/10.5010/ JPB.2019.46.1.017.

Mohanty, S., Panda, M.K., Sahoo, S., and Nayak, S. (2011). Micropropagation of Zingiber rubens and assessment of genetic stability through RAPD and ISSR markers. Biol. Plant. 55(1), 16-20. https://doi.org/10.1007/s10535-011-0002-1.

Murashige, T., and Skoog, F. (1962). A revised medium for rapid growth and bioassays with tobacco cultures. Physiol. Plant 15, 473497. https://doi.org/10.1111/j.1399-3054.1962.tb08052.x.

Noguchi, Y., and Yamakawa, O. (1988). Rapid clonal propagation of ginger (Zingiber officinale Roscoe) by roller tube culture. Japan J. Breed. 38(4), 437-442. https://doi.org/10.1270/jsbbs1951.38.437.

Prasad, S., and Tyagi, A.K. (2015). Ginger and its constituents: role in prevention and treatment of gastrointestinal cancer. Gastroent. Res. Pra. https://doi.org/10.1155/2015/142979.

Rajani, H., and Patil, S.S. (2009). In vitro response of different explants' types on shoot and root development of ginger. Acta Hortic. 829, 349-353. https://doi.org/10.17660/ActaHortic.2009.829.55.

Rout, G.R., Palai, S.K., Samantaray, S., and Das, P. (2001). Effect of growth regulator and culture conditions on shoot multiplication and rhizome formation in ginger (Zingiber officinale Rosc.) in vitro. In Vitro Cell. Dev. Plant 37(6), 814-819. https://doi.org/10.1007/ s11627-001-0135-6.

Seran, T.H. (2013). In vitro propagation of ginger (Zingiber officinale Rosc.) through direct organogenesis: A review. Pak. J. Biol. Sci. 16(24), 1826-1835. https://doi.org/10.3923/pjbs.2013.1826.1835.

Sharma, T.R., and Singh, B.M. (1997). High-frequency in vitro multiplication of disease-free Zingiber officinale Rosc. Plant Cell Rep. 17(1), 68-72. https://doi.org/10.1007/s002990050354.

Shukla, Y., and Singh, M. (2007). Cancer preventive properties of ginger: A brief review. Food Chem. Toxicol. 45(5), 683-690. https:// doi.org/10.1016/j.fct.2006.11.002

Sundararaj, S.G., Agrawal, A., and Tyagi, R.K. (2010). Encapsulation for in vitro short-term storage and exchange of ginger (Zingiber officinale Rosc.) germplasm. Sci. Hortic. 125(4), 761-766. https:// doi.org/10.1016/j.scienta.2010.06.001.

Thingbaijam, D.S., and Huidrom, S.D. (2014). High frequency plant regeneration from transverse thin cell layer section of in vitro derived 'Nadia' ginger microrhizome. Not. Sci. Biol. 6(1), 85-91. https://doi.org/10.15835/nsb619225.

Tyagi, R.K., Agrawal, A., and Yusuf, A. (2006). Conversation of Zingiber germplasm through in vitro rhizome formation. Sci. Hortic. 108(2), 210-219. https://doi.org/10.1016/j.scienta.2006.01.018.

Wang, B., Li, J.W., Zhang, Z.B., Wang, R.R., Ma, Y.L., Blystad, D.R., Keller, E.R.J., and Wang, Q.C. (2014). Three vitrificationbased cryopreservation procedures cause different cryo-injury to potato shoot tips while all maintain genetic integrity in regenerants. J. Biotechnol. 184, 47-55. https://doi.org/10.1016/j. jbiotec.2014.04.021.

Wang, Q.C., and Valkonen, J.P.T. (2009). Cryotherapy of shoot tips: Novel pathogen eradication method. Trends Plant Sci. 14(3), 119122. https://doi.org/10.1016/j.tplants.2008.11.010.

Wilson, R., Haniadka, R., Sandhya, P., Palatty, O.L., and Baliga, M.S (2013). Ginger (Zingiber officinale Roscoe) the dietary agent in skin care: A review. In Bioactive Dietary Factors and Plant Extracts in Dermatology (Humana Press). https://doi.org/10.1007/978-162703-167-7_11. 
Yamuna, G., Sumathi, V., Geetha, S.P., Praveen, K., Swapna, N., and Babu, K.N. (2007). Cryopreservation of in vitro grown shoots of ginger (Zingiber officinale Rosc.). CryoLetters 28(4), 241-252.

Yi, L.T., Xu, Q., Li, Y.C., Yang, L., and Kong, L.D. (2009). Antidepressantlike synergism of extracts from magnolia bark and ginger rhizome alone and in combination in mice. Prog. Neuropsychopharmacol. Biol. Psychiatry 33(4), 616-624. https://doi.org/10.1016/j. pnpbp.2009.03.001.

Yin, Z.F., Zhao, B., Bi, W.L., Chen, L., and Wang, Q.C. (2013). Direct shoot regeneration from basal leaf segments of Lilium and assessment of genetic stability in regenerants by ISSR and AFLP markers. In Vitro Cell. Dev. Plant 49(3), 333-342. https://doi.org/10.1007/s11627013-9501-4.

Zhang, C., Yu, C.H., and Peng, C. (2012). The research progress of fresh ginger dry ginger and which are authentic herb in Sichuan. Pharm. Clin. Chin. Mat. Med. 3(6), 56-58 (in Chinese with English abstract).

Zuraida, A.R., Shukri, M.A.M., Sabrina, M.N.E., Nazreena, O.A., Radziah, C.T.C., Pavallekoodi, G., and Sreeramanan, S. (2016). Micropropagation of ginger (Zingiber officinale var. Rubrum) using buds from microshoots. Pak. J. Botany 48, 53-62.

Received: Oct. 23, 2019

Accepted: Apr. 6, 2020

Addresses of authors:

R.R. Wang ${ }^{1, * *}$, C.C. Liu ${ }^{1, * *}$, L.J. Wang ${ }^{1}$, M.Y. Yuan ${ }^{1}$, M.Y. Zeng ${ }^{2}$,

J. $\mathrm{Li}^{1}$ and Z.K. Tang ${ }^{1, *}$

${ }^{1}$ School of Life Science and Engineering, Southwest

University of Science and Technology, Mianyang 621010,

Sichuan, People's Republic of China

${ }^{2}$ School of Civil Engineering and Architecture, Southwest

University of Science and Technology, Mianyang 621010,

Sichuan, People's Republic of China

* Corresponding author; E-mail: tzkyaan@swust.edu.cn Tel.: +86 816 6089534; Fax: +86816 6089534

** These authors contributed equally to this study. 